\title{
Foreign Language Teaching with Integration of Cultural Content
}

\author{
Paed Dr. Eva Habiňáková, PhD
}

\author{
Department of Linguistic Communication, Faculty of Mass Media Communication \\ University of Ss. Cyril and Methodius in Trnava; eva.habinakova@ucm.sk
}

Doi:10.5901/mjss.2016.v7n1s1p299

\begin{abstract}
The author of the paper deals with the concept of teaching a foreign language with integrated cultural element. She derives her knowledge from the model of communicative competence and the latest model of intercultural communicative competence. On the basis of professional publications in the given area the author defines the goals of foreign language teaching and tries to specify the content of teaching which should be focused on support and development of students' communicative competence. Speaking about the integration of cultural content into foreign language teaching we also have to deal with the form of such integration.
\end{abstract}

Keywords: teaching, foreign language, cultural content, competence, objectives of foreign language teaching

\section{Introduction}

"It is not only the cooperation between people and individuals [that matters]; there also is a dialogue of cultures, of civilisations. And today we understand that we must learn how to conduct such a dialogue; a dialogue that will help to make the achievements of the different cultures and civilisations the property of all mankind." (Bogoliubov and Lazebnikova in Coulby et al., 1997) The present day position and importance of English can be summed up as follows:

- It is a fact that English has become lingua franca, language of the world, language of international communication, i.e. people speaking various native languages are able to communicate and share their knowledge, opinions, attitudes, etc.

- English has become the language of science and technology, the language of progress. Most of the professional literature all over the world is published mainly in English.

- Countries with significant and influential political and economic power have more than 300 million monolingual (English speaking) citizens.

- Schools, colleges and universities all over the world offer their students English as first foreign language they can learn.

- English is the global media language.

The importance of English in the world of science is constantly growing. Not only is it the major language of direct communication between scientists worldwide, it has also started to replace the use of other traditionally important languages in scientific publications. Although English is not the language with the greatest number of native speakers in the countries of the European Union, its importance for communication becomes even bigger. (Witt, 2000) English has become the dominant language in mass media, business and foreign language learning/teaching. $A$ foreign language is nowadays considered a communication tool with the emphasis on communicative objectives. The Slovak curricula and Common European Framework for Languages point out the benefits of foreign language learning for the level and quality of general knowledge. Speaking more than one foreign language in the world of $21^{\text {st }}$ century has become both matter of course and a necessity. The issue of language literacy has been coined. Students will face several situations, both in private and professional lives, in which they will need to speak and understand a foreign language. High mobility of modern times will set our students into situations of direct interaction with native speakers in the target language countries. On the other hand, our students can become hosts to people from target language culture in their domestic environment. Not to forget, when speaking about English language, it will help them communicate with people from various cultures from all over the world. Based on the above mentioned facts, we can state that to educate and produce an interculturally competent student, we have to pay more attention to a more complex preparation of future language teachers. 


\section{Communicative Competence}

When discussing the concept of language teaching with integrated cultural element we build upon the model of communicative competence and the model of intercultural communicative competence. In communicative language teaching a language and culture are inseparable. Their mutual relations influence the course of communication. The model of communicative competence applied at our schools in the practice of teaching foreign languages consisted of four competences:

- Grammatical competence is in broader sense understood as linguistic competence including not only morphology and syntax but also lexicology, phonetics and orthography.

- Sociolinguistic competence assumes the knowledge of a social context and communicative situation. It relates to all four communicative skills as it includes the expression and understanding of proper social meanings in various social contexts and expression and interpretation of linguistic forms.

- Strategic competence relates to strategies by which the insufficient mastering of rules is compensated. Strategic competence helps to deal with lexical and grammatical problems when reading and writing by means of grammar books, dictionaries or by guessing the meaning of a lexical unit by the context.

- Discourse sub-competence should be understood as the ability to produce a consistent discourse.

Within the framework of the described model of communicative competence teaching of culture is focused on students' communication with representatives/members of the target language culture. The objectives of such teaching are based on specific approach to intercultural communication dealing with the understanding of a specific cultural system and identification of differences between cultures that are perceived as a source of misunderstandings and conflicts. For them the solutions are to be found. Valette (1986) defines the objectives of foreign language teaching with the target language culture included on the basis of cognitive and affective aims as follows:

- Broader cultural awareness and knowledge of students about the target culture, life, geographic, historic, economic, artistic and scientific aspects of target society, awareness about differences in everyday life, differences in values and attitudes between student's own culture and the target language culture.

- Knowledge about etiquette of target culture, polite behaviour expected from a foreigner by a member of the target culture, description of proper behaviour, etiquette and reactions appropriate in specific situations in the target culture.

- Understanding the differences between one' s own and target culture (various forms of serving meals, different meanings of signs and symbols, schedules, newspaper advertisements, filling in cheques, buying a travel ticket, etc.).

- Understanding the values of target culture, interpretation of behaviour of target culture members according to their values system.

Seelye (1984) presents similar definition of objectives. He claims a student should be able to act appropriately in a society of target language culture and communicate with members of a given culture. A student should be able to:

- $\quad$ understand the behaviour of people when satisfying their basic physiological and psychological needs;

- $\quad$ understand the impact of social factors (age, gender, social class, status, discourse, behaviour);

- understand conventions in the behaviour of people in common and crisis situations in target culture;

- show the awareness about connections between culturally determined images, words and phrases;

- $\quad$ assess generalisations related to target culture by arguments supporting them;

- localise and organise information about target culture acquired from libraries, media, personal experience, people, etc.;

- show interest in target culture and empathy to its members.

Both authors emphasise the importance of cognitive development. It is crucial to learn not only the foreign language but also the target language culture.

Doyé (1991) points out the interconnection between teaching and educational objectives and the objectives of foreign language teaching. He defines three basic objectives of such teaching: cognitive, evaluative and conative. Doyé understands cognitive objectives as acquisition of knowledge and information and subsequent understanding of nations and their cultures. The interconnection between foreign language teaching and teaching culture of the target language is in broadening the existing knowledge of students about the scheme of a new culture. The evaluative objectives include the minimization of ethnocentric judgements and open attitude towards the values of a new culture. Being taught a foreign language students come into contact with a new culture. Influenced by it they reassess their existing values. The third element is the readiness to act with the representatives of other cultures on the basis of tolerance, respect and openness. The mentioned categories have the potential to combine common educational goals and the goals of teaching 
a foreign language and culture.

Byram and Fleming (1998) state that within communicative competence "people are using the same language in the same, or closely related way, cultures rely." It is generally known that the theoretical grounds of the communicative competence model were established by Hymes when he critically reflected on the competence/performance dichotomy of Chomsky. Nowadays there are many existing models of communicative competence. This phenomenon can be ascribed to the fact that within the definition of the basic principles of communicative teaching there was introduced the requirement to clearly determine and classify the knowledge and skills of the language user to begin with the needs of educational practice but also too clearly define which of the aspects of the language performance should be the subject of our efforts with the respect to interpersonal communication improvement. Savignon states (Savignon, 1983): "Communicative competence is rather dynamic than a static concept. It depends on the negotiation of meaning between two or more people who share to some degree the same symbolic system. Communicative competence can be said to be an interpersonal rather than an intrapersonal trait. It applies to both written and spoken language as to many other symbolic systems. Communicative competence is context specific. Communication takes place in an infinite variety of situations, and success depends on one's understanding of the context or on prior experience of a similar kind. It requires making appropriate choices of register and style in terms of situation and the other participants. There is a theoretical difference between competence and performance. Competence is defined as a presumed underlying ability and performance as the overt manifestation of that ability. Competence is what one knows, performance is what one does. Only performance is observable. It is only through performance that competence can be developed, maintained and evaluated. Communicative competence is relative, not absolute and depends on the cooperation of all the participants involved. It makes sense then to speak of degrees of communicative competence."

Only by adding the word intercultural, the definition changes a bit. According to Byram and Fleming (1998) the intercultural or cross-cultural communicative competence "depends on the acquisition of abilities to understand different modes of thinking and living, as they are embodied in the language to be learnt, and to reconcile or mediate between different modes in any specific interaction." These two notions should not be mixed.

\section{Intercultural Communicative Competence}

Focusing on intercultural communicative competence, it has to be considered that one thing that intercultural, international and development communication share in common is the focus on culture. Intercultural communication is defined as communication between people from different national cultures. Many scholars narrow its scope down to face to face communication. Wiseman (2001) notices that: "Intercultural communicative competence has been investigated in studies with diverse conceptual foci as "immigrant acculturation, intergroup contact, culture shock, cross-cultural training, social change, international management and foreign student advising. Some of these conceptualizations were labelled as cross-cultural adjustment, cross-cultural adaptation, intercultural understanding, overseas success, personal growth/adjustment, cross-cultural effectiveness and satisfaction with overseas experience. The intercultural communicative competence involves the knowledge, motivation and skills to interact effectively with members of different cultures." Learners are supposed to acquire the linguistic competence needed to communicate in speaking or writing, to formulate what they want to say/write in a correct and appropriate way. Intercultural communication is based on respect for individuals and equality of human rights as the democratic basis for social interaction. (Byram, Gribkova, Starkey, 2002)

The objectives of teaching culture according to the model of intercultural communicative competence assume along with shaping cultural awareness about one's own culture and the foreign culture also shaping an individual's personal traits and general communicative skills. Damen (1987) and Byram (1997) specify the objectives for teaching a foreign language and culture. Damen defines them as follows:

- Raising the cultural awareness about one's own and target culture;

- Supporting tolerance and acceptance of diverse values, attitudes and beliefs as part of target culture;

- Understanding new and different target patterns;

- Developing intercultural communicative skills in areas where similarities between cultures can be found;

- Developing intercultural awareness, learning about cultural diversities and understanding the influence of a diversity;

- Developing the attitudes of change acceptance and personal adaptation.

Within the specification of objectives Damen combines cognitive and affective levels and stresses the need to learn language and its culture as a lifelong process. Byram (1997) also emphasises the need to form and raise intercultural communicative competence of students. He specifies its components as follows: 
- Attitudes of interest and openness, the will to get rid of mistrust of other culture and exclusive trust of one's own culture;

- Knowledge about products and habits of social group in one's own culture and in the culture of communication partner, knowledge about general processes in social and individual interaction;

- Skills of interpretation and search for connections, ability to interpret a document or event in another culture, to explain it and relate to documents or events in one's own culture;

- Skills to discover and interact, ability to acquire new knowledge about culture, apply the acquired knowledge, attitudes and skills in communication and interaction in real life;

- Critical cultural awareness and citizenship education, ability to critically assess perspectives, habits and products of one's own culture and other cultures.

Intercultural communicative competence has developed on the basis of several proposed objectives. The objectives include knowledge, skills, awareness and attitudes. Knowledge refers to national and cultural identity, patterns of behaviour in everyday life, place and space (geographical and social), social diversity, foreign influences, how institutions work, dissemination of information and distribution of artistic and cultural products. Skill is the ability to observe and identify relevant cultural themes, patterns and value orientations, to observe and identify patterns of verbal and nonverbal behaviour and to form appropriate cultural hypotheses related to behaviour, perceptions and expectations. The awareness and attitudes should develop a positive attitude towards cultural otherness, expand cultural awareness of both the student's native and target cultures, refer to culture and encourage curiosity and the wish to understand other cultural patterns.

Building the intercultural communicative competence in foreign language teaching should according to Byram represent an integral part of general educational goals of the school system.

In Slovakia the document responding to such challenges is the National educational programme. It specifies curricula for individual language levels (A1-B2) as follows: "The aim of submitted curricula is to provide the learners not only with a complex of linguistic competences but also with general competences to make their linguistic preparation effective in response to the requirements of a modern democratic European citizen who is ready to live in united Europe." (Štátny pedagogický ústav, 2012) The need of lifelong learning is explicitly emphasized in the programme by stating: "To understand the language education as education for life allows each individual to live according to his/her own wish and satisfaction." (ibid). How to integrate the target language culture into foreign language teaching? We believe that a systematic integration of teaching culture should be reflected in curricula and included among goals of English language teaching at secondary (grammar) schools. We propose following ideas:

- Support and motivate the students in their permanent and active interest in the target language culture and people living in the country.

- Provoke and support students' values such as tolerance, empathy and respect for other cultures.

- Support a multi-perspective view of the world (cosmopolitan world of the $21^{\text {st }}$ century).

- Work on students' understanding of how to use a language and socio-cultural context of using both the mother tongue and a foreign language.

- Provide students with ways of verbal and non-verbal behaviour in the target language culture and show equivalents of such behaviour in one's own country.

- Develop the understanding of connotative meanings of words.

- Develop cultural awareness about similarities and differences between one's own culture and target language culture.

- Work on students' critical approach to generalizing statements and stereotypes.

- Improve the skills to search and process and information about own culture and target language culture as a base for further education in the future.

Having specified the goals we need to set the content of teaching that will raise the intercultural communicative competence among students. When defining the content we face the question how to teach rather than what to teach.

\section{Cultural Content and Its Integration into Foreign Language Teaching}

The main effort of modern foreign language teaching and its culture is to dive into the perception of understanding the reality by native speakers. Stern (1992) selects following areas for teaching cultural content:

- Geography (perception of geographic areas by native speakers, their cultural associations).

- Individuals and their way of life (values, problems, lifestyle of native speakers).

- People and society (relationship individual - group, image of social life). 
- History (important events and personalities assessed by native speakers).

- Institutions (army, media, government, political and educational systems, religious institutions, etc.).

- $\quad$ Art, life and literature (knowledge about artists, writers and their important works).

Majority of selected areas of cultural content corresponds with the proposal of Minimal Content by Byram (1993). Modern approaches to the definition of cultural content in foreign language teaching are based on social anthropology and interpretative culture research. The selected cultural content must be specified also by a definition of competences that are to be developed to reach the objectives of foreign language teaching. Cultural content should cover these areas:

- Behaviour of target culture members in everyday situations (greetings, saying goodbye, polite phrases, formal and informal models of behaviour).

- Culturally specific phenomena and naming objects of extra-lingual reality which in the learner' s culture does not have an equivalent.

- Characteristics of subcultures in the target language culture.

- Institutions of socialization in the target language culture (school, family, media).

- Way of thinking among members of particular culture, system of values, attitudes,, problem solving, behaviour in critical situations).

- Geography, places of special importance for members of given culture.

- Historically important events and personalities that influenced national identity.

- $\quad$ Art (art products, personalities, their work).

- Representation of oneself and "the others", relationship between target language country and the country of people/students learning that language.

Selected cultural content is to be continually developed and completed with further knowledge and information. This process must be systematic not randomly included into foreign language teaching. The knowledge of cultural content can be extended by the interdisciplinary knowledge of students. However, it is necessary to consider their age and language level.

Based on the above stated we believe that the main objective of foreign language teaching is to raise the intercultural communicative competence. Foreign language teaching should respect the principles of communicative teaching and cover the linguistic area and cultural awareness of students. When selecting or creating the activities we have to consider the methodological procedures such as order (from simple to more complicated, form behavioural to abstract), principle of activity (support students' activity, motivate them, develop their cognitive processes and motivation to autonomous learning), principle of comparison (showing the differences, teach how to understand them, search for similarities in cultural systems and non-verbal expressions), principle of interpretation (when interpreting texts and communication itself), critical approach (to one's own culture and foreign language culture).

Communicative situation can involve also non-verbal expressions. Non-verbal dimensions of communication refer to body language, object language and environmental language. Body language means facial movements, gestures, taction, etc. Object language refers to artefacts, clothing, etc. and environmental language refers to architecture, colours and space (Morain, 1986). As suitable exercises we recommend simulation games, role plays, questions and answers, fulfilling tasks, etc.

Role plays and simulation games aim to teach how to understand emotional experience and practice the modification of behaviour. CDs or DVDs are often used and serve as basis for discussions or simulations of situations. We can also add group discussions, self-awareness exercises, case studies or decision-making tasks based on group consensus. Case studies are also popular and applicable exercises. They include critical incidents, case studies and cultural assimilators.

Critical incidents consist of several incidents describing various situations and agents. Case studies consist of several incidents connected by one situation and common agents. The choice of either a critical incident or a case study depends on depth of culture analysis, i.e. the range of various situations we want to cover. Critical incidents and cultural assimilators resemble each other in describing cultural differences in various situations. They differ in their use. Cultural assimilators besides the case itself offer several possible interpretations of why the incident occurred. The choice of a correct interpretation depends on the level of knowledge about culture or a concept described in an incident. Critical incidents do not offer possible interpretations, they expect a student to analyze and come up with his/her own interpretation. All three types of exercises can be combined. Talking about the vocabulary students must be introduced to the concept of another culture the vocabulary of which can seem similar to student's own culture. However, the student must be made aware of the mutually determined relationship between language and culture. Teachers should highlight the differences based on extra-lingual reality, unique objects in a culture (Slovak halushki, English potluck) and different meaning of words that might seem identical (window, tea, etc.). Students' activities should be focused on activities with 
authentic materials (magazines, newspapers, and books), presentation of diverse audiovisual materials demonstrating a selected concept in the target language community and student's own. When mentioning newspapers, we would like to draw attention to the possibility of using digital (online) newspapers in foreign language teaching. They are not expensive, easily available and bring topical information in authentic foreign-language texts, which can support and improve cultural awareness and better understanding of the target language (Ungerová, 2014). It is also possible to use statistic data and graphs enabling the understanding of native speaker's reality. Proverbs and sayings in the target language culture are also a suitable way how to compare individual cultures or values. Proverbs illustrate type of behaviour typical for a culture. In exercises teachers and students can search for similar proverbs and sayings in their mother tongue and language of the target culture or they can compare symbols expressing these values, i.e. Look before you leap./Dvakrát meraj, raz rež., black sheep of the family - čierna ovca rodiny). Habiňák (2012) explains and reasons the importance of teaching phraseology. He believes that idioms develop knowledge, creative thinking and sense for linguistic matters. A student who is aware of idioms can improve his/her stylistic skills. Idioms cultivate readers and they also shape students' attitudes to common knowledge and ethics of behaviour in the target language culture. Moreover, both cultures (native and target language culture) might overlap and influence each other, i.e. in vocabulary. English penetrates into Slovak vocabulary with words we define as Anglicisms. Many of them are culturally determined and to understand them requires some background cultural knowledge. (Habiňák, 2013).

Another option when including cultural content into foreign language teaching is to use literary texts and literature produced in the target language culture. There are two views on the use of literary texts. One group of professionals (Valdes, Seeley) unequivocally supports the inclusion of literary texts into foreign language teaching as part of presented cultural content. By literary texts we mean extracts from novels, poems, dramas, etc. More modern approaches to literature do not see it as source of behaviour patterns typical for a culture. They stress interpretation, space for discussion, student's personal experience, perception of reality and comprehension of a text.

It is mainly student's personal experience that helps to understand the target language culture. Effective intercultural communication requires student's personal experience, observation and critical analyzing. We could mention also the importance of even shorter study stays in the target language culture. Discovering the connection between culture and behaviour of its members may motivate a student to further study of a foreign language.

\section{Conclusion}

In the paper the author deals with intercultural approach to teaching a foreign language (English). She defines communicative and intercultural competence as both of them are objectives in foreign language teaching. Further on, on the basis of professional literature published in this area she defines cultural content and its components. It was necessary to rely on educational documents for teaching English in Slovakia to emphasize that culture and language are inseparable and when teaching English the English culture must be included into the educational process. Having defined the content the author presents several possible methods of its implementation into language classes. The dynamic era we live in expects us to be interculturally competent citizens. To speak is no longer sufficient. What is important is to understand.

\section{References}

Byram. M. (1993). Criteria for Textbook Evaluation. Frankfurt am Main: Verlag Moritz Diesterweg. p. 34-38.

Byram, M. (1997). Teaching and Assessing Intercultural Communicative Competence. Clevedon. Multilingual Matters Ltd. p. 50-53.

Byram, M., Fleming, M. (1998). Language Learning in Intercultural Perspective. Cambridge University Press. ISBN 0-521-62559-9. p. 12.

Byram, M., Gribkova B., Starkey, H. (2002). http://www.coe.int//dg4/linguistic/Source/Guide dimintercult En.pdf, p. 9- 10.

Coulby, D., Gundara, J., Jones, C. (1997). Intercultural Education - World Yearbook of Education 1997. British Library Cataloguing in Publication Data. ISBN 0-7494-2114-2. p.7.

Damen, L. (1987). Culture Learning: The Fifth Dimension in the language Classroom. Reading, Massachusets: Addison-Wesley Publishing Company. ISBN 020111478X. p. 247-248.

Doyé, P. (ed.) (1991). Grossbritanien. Seine Darstellung in deutschen Schulbüchern für den Englischunterricht. Frankfurt. Verlag Moritz Diesterweg. p. 16-19.

Gudykunst, W.B., Moody, B. (2002). Handbook of International and Intercultural Communication. Sage Publication. ISBN 0-7619-2090-0. p. $207-208$.

Habiňák, A. (2012). Frazeológia a frazeogramotnost' na základných školách. Univerzita sv. Cyrila a Metoda v Trnave. Trnava. ISBN 97880-8105-390-0. p. 35.

Habiňák, A. (2013) Prenikanie anglicizmov do slovenčiny. In: Dotyk zla: mediálna výchova a výchova médií - Megatrendy a médiá 
2013.Fakulta masmediálnej komunikácie UCM v Trnave. Trnava. ISBN 978-80-8105-478-5. p. 29-33.

Morain, G. (1986) Kinesics and cross-cultural understanding. In: Valdes, M. (ed.): Bridging the Cultural Gap in Language Teaching. Cambridge: Cambridge University Press. p. $64-76$.

Savignon, S. J. (1983). Communicative competence: Theory and classroom practice. Reading, MA: Addison-Wesley. p. 8-9.

Seelye, N. H. (1984). Teaching Culture: Strategies for Intercultural Communication. Lincolnwood, Illinois. National Textbook Company. p. 49.

Stern, H.H. (1992). Issues and Options in Language Teaching. Ed. by P. Allen and B. Harkey. Oxford: OUP. ISBN 0-415-12085-3. p. 125.

Štátny pedagogický ústav. (2012). http://www.statpedu.sk/files/documents/cp-2013-2014/cp_anglicky_jazyk_b2_2013_2014.pdf

Ungerová, M. (2014). Digital Newspapers in English-Language Teaching. In: Nedoma, R. (ed).: Foreign language competence as an integral component of the university graduate profile. Brno. ISBN 978-80-7231-981-7. p. 348-352.

Valette, R.M. (1986). The Culture Test. In: Valdes, M. (ed).: Bridging the Cultural Gap in Language Teaching. Cambridge. Cambridge University Press. p. 179-197.

Wiseman, R.L. (2001). http://commfaculty.fullerton.edu/rwiseman/ICCCpaper.htm

Witt, J. (2000). http://webdoc.sub.gwdg.de/edoc/ia/eese/artic20/witte/6_2000.html 